\title{
Janusz Gręźlikowski
}

\section{Komunia pod dwiema postaciami w ustawodawstwie synodalnym Polski przedrozbiorowej}

Prawo Kanoniczne : kwartalnik prawno-historyczny 47/1-2, 151-180

2004

Artykuł został zdigitalizowany i opracowany do udostępnienia w internecie przez Muzeum Historii Polski w ramach prac podejmowanych na rzecz zapewnienia otwartego, powszechnego i trwałego dostępu do polskiego dorobku naukowego i kulturalnego. Artykuł jest umieszczony w kolekcji cyfrowej bazhum.muzhp.pl, gromadzącej zawartość polskich czasopism humanistycznych i społecznych.

Tekst jest udostępniony do wykorzystania w ramach dozwolonego użytku. 


\section{KOMUNIA POD DWIEMA POSTACIAMI W USTAWODAWSTWIE SYNODALNYM POLSKI PRZEDROZBIOROWEJ}

Treść: Wstęp; 1. Komunia pod dwiema postaciami w ustawodastwie powszechnym Košcioła; 2. Regulacje polskiego ustawodastwa synodalnego; Zakończenie.

\section{Wstęp}

Pośród licznych kontrowersji dotyczących Eucharystii w dziejach Kościoła na czolowe miejsce wysuwa się sprawa sposobu przyjmowania Komunii świętej przez wiernych. Odnosi się to szczególnie do kwestii przyjmowania Komunii pod dwiema postaciami, która stała się, wbrew woli samego Chrystusa, przedmiotem licznych sporów, określeń, pozwoleń, nakazów i zakazów. Przyjmowana Eucharystia zamiast jednoczyć i bratać, stała się jednym z głównych przedmiotów niezgody?. Przez prawie trzynaście wieków w Kościele Zachodnim zwyczajną i powszechną praktyką komunikowania wiernych była Komunia pod postaciami chleba i wina, która do dziś jest zachowana w niektórych katolickich Kościołach Wschodnich ${ }^{2}$. Na przełomie XII i XIII wieku na drodze zwyczaju przyjęła się praktyka Komunii pod jedną postacią, tj. chleba i stanowiła powszechną zasadę przez prawie siedem stuleci ${ }^{3}$, aż do 4 grudnia 1963 r., kiedy to Sobór Watykański II w Konstytucji o Liturgii postanowil przywrócić w ograniczonym zakresie Komunię pod dwiema postaciami $^{4}$, a co usankcjonował Kodeks Prawa Kanonicznego z 1983 r. ${ }^{5}$

\footnotetext{
' P. Szczaniecki, Niektóre źródla dotyczace kultu Eucharystii w Polsce 1350-1450, Archiwa, Biblioteki i Muzea Kościelne 21 (1970) s. 196.

' J. Mielczarek, Komunia pod dwiema postaciami w ustawodawstwie Kościola zachodniego, Lublin 1983, s. 12.

${ }^{3}$ Wyrazicielem tej praktyki był Kodeks Prawa Kanonicznego z 1917 r., który jednoznacznie stanowil: Sanctissima Eucharistia sub solo specie panis praebeatur. Zob. Kan. 853 KPK z 1917 r.

${ }^{4} \mathrm{KL} 55$.

'Kan. 925 KPK; Zob. Congregatio pro Cultu Divino, Instructio Sacramentali Communione de ampliore facultate sacrae Communionis sub utraque specie administratione
} 
W wieku XV został zapoczątkowany ruch na rzecz rewindykacji Komunii kielicha dla wiernych świeckich, który pojawił się i rozwijał w szerokim nurcie husycyzmu. Ruch ten ujawnił się ponownie - ze wzmożona moca - w dobie reformacji protestanckiej. Kościól swoje stanowisko wobec tych dążeń zajmował w czterech zasadniczych momentach, a mianowicie na soborach w: Konstancji (1414-1418), Bazylei (1431-1437), Trydencie (1545-1563) i wspomnianym Watykańskim II (1962-1965). Ruch więc na rzecz Komunii pod dwiema postaciami kształtował się w różnych epokach i nie był wolny od procesów religijnych, spolecznych i politycznych ówczesnych epok. Odbił się także szerokim echem w polskim ustawodawstwie synodalnym tamtego okresu, które miało za zadanie wprowadzać w życie prawo powszechne odnoszące się do sposobu przyjmowania Komunii świętej, jak też dyscyplinować i regulować wszelkie niewłaściwe tendencje zmierzające do wprowadzenia Komunii pod dwiema postaciami.

Opracowanie ma za zadanie przyblizyć i omówić zagadnienie Komunii świętej pod dwiema postaciami wiernych obrządku łacińskiego w ustawodawstwie synodalnym Polski przedrozbiorowej, które było ważnym czynnikiem i narzędziem wprowadzania w życie poszczególnych Kościołów lokalnych uchwał soborów, a szczególnie reformistycznych postanowień Soboru Trydenckiego, jakże ważnego dla prezentowanego zagadnienia Komunii sub utraque specie tamtego czasu.

\section{Komunia pod dwiema postaciami w ustawodawstwie powszechnym Kościola}

Bóg zgodnie ze swoją pedagogią dostosował się do ludzkiego sposobu pojmowania i proces przyswajania życia Bożego ubral w szatę spożywania najbardziej rozpowszechnionego pokarmu i napoju, chleba i wina ${ }^{6}$. Przyjmowanie zatem sakramentu Eucharystii dokonuje się z woli Bożej na sposób spożywania pokarmu. Stanowi to istotny symbolizm sakramentu Eucharystii, objawiający jego cel i skutki - symbolizm nakarmienia, posilenia i dania życia?.

(29. VI. 1970), AAS 62 (1970) 664-667; T. Pawluk, Prawo kanoniczne wedlug Kodeksu Jana Pawla II, t. II, Olsztyn 1985, s. 388-390.

${ }^{6}$ B. Pylak, Eucharystia sakramentem jedności Mistycznego Ciala Chrystusa. Koncepcja św. Tomasza z Akwinu, Warszawa 1972, s. 147.

'J. Journet, Msza święta. Obecność Ofiary Krzyżowej, Poznań-Warszawa-Lublin 1959, s. 237. 
Komunia pod dwiema postaciami ma swoje źródło w słowach Chrystusa. Swoją wolę w tej sprawie objawił Apostołom w Wielki Czwartek ${ }^{\star}$, co potwierdzil autorytatywnie Sobór w Konstancji: Chrystus po Wieczerzy ustanowit i dat uczniom pod dwiema postaciami chleba $i$ wina ten czcigodny Sakrament ${ }^{9}$.

Kościół od samego początku przykład i polecenie Chrystusa rozumiał dosłownie i polecał kapłanom w czasie sprawowania Eucharystii zawsze modlić się nad chlebem i winem, by stały się Jego Ciatem i Krwią. Słowa Chrystusa bierzcie i jedzcie, bierzcie i pijcie wraz z poleceniem to czyńcie na moja pamiątkę, zdają się wyraźnie i przekonywująco wskazywać na Komunię pod dwiema postaciami, jako sposób komunikowania zgodny z Jego wolą. Przekazy ewangeliczne zawierają jednak również słowa Chrystusa, które wyraźnie uzasadniają wystarczalność Komunii tylko pod jedną postacią chleba ${ }^{10}$.

Podwójna możliwość komunikowania, a mianowicie pod jedną lub pod dwiema postaciami, posiada zatem podstawę doktrynalno-prawną w nauce samego Chrystusa. Toteż chrześcijanie pierwszych wieków przyjmowali Eucharystię zarówno pod jedną, jak i pod dwiema postaciami". Nie uważano nigdy Komunii pod dwiema postaciami za wyłącznie konieczną do pełnego udziału w owocach tej tajemnicy, czy nawet do zbawienia ${ }^{12}$. Wskazują na to wyraźnie świadectwa Ojców Kościoła i pisarzy kościelnych ${ }^{13}$. W ten sposób była odczytywana, rozumiana i wypełniana wola i intencja samego Chrystusa w tej sprawie przez pierwotny Kościól. Chociaż daje się zauważyć w pierwszych wiekach chrześcijaństwa pewne preferowanie Komunii pod dwiema postaciami. Co więcej, należy podkreślić, że sposób komunikowania $z$ Wieczernika tzn. pod dwiema postaciami był od początku poprzez blisko dwanaście wieków praktyką dominującą w Kościele ${ }^{14}$. Fakt ten

\footnotetext{
${ }^{8}$ Mt 26, 26-28; Mk 14, 22-24; Lk 22, 20; J 6, 53; 1 Kor 11, 24-26.

${ }^{9}$ Conc. Constantiense, sess. XIII, Decretum Cum in nonnullis. Denzinger 626; Zob. Concilionum Oecumeniconum Decreta, Bologna 1973, s. 419.

"J 6, 48-51; J 5, 58; Dz 2, 42.

"Sakramenty wtajemniczenia chrześcijańskiego. Pr. zb. pod red. J. Kudasiewicza, Warszawa 1981, s. 336;. Zob. J. Mielczarek, Komunia pod dwiema postaciami..., dz. cyt., s. 18.

${ }^{12}$ Sakramenty wtajemniczenia chrześcijańskiego..., dz. cyt., s. 336-337; Zob. J. Mielczarek, Komunia pod dwiema postaciami..., dz. cyt., s. 19.

${ }^{13}$ Sakramenty wtajemniczenia chrześcijariskiego..., dz. cyt., s. 332, 343.

${ }^{14}$ Taki okres czasu ustala powszechnie i zgodnie literatura historyczno-teologiczna. Por. P. Rzymski, Wklad obrzędów kościelnych, historyczny i duchowy, Warszawa 1857 , s. 88; J. A. Jungmann, Liturgie der christlichen Frühzeit, Freiburg 1967, s. 209-210.
} 
potwierdza niemała liczba świadków w ciągu pierwszego tysiąclecia chrześcijaństwa ${ }^{15}$. Trzeba jednak zauważyć, iż obok tej zasadniczej i zwyczajowej praktyki Komunii, równolegle było dozwolone i tolerowane komunikowanie pod jedną postacią, chleba lub wina, ale tylko w szczególnych wypadkach i sytuacjach ${ }^{16}$. Swiadczy to, że Kościól ze swej strony nie widział w tych dwóch sposobach komunikowania problemu doktrynalnego i wszelkie konieczne rozstrzygnięcia w tej materii traktował jako sprawę jedynie dyscypliny kościelnej ${ }^{17}$.

Mimo tego nie zdołano uniknąć i usunąć niebezpieczeństwa błędów będących w sprzeczności z działaniem i intencja Chrystusa. Już w II wieku pojawili się Akwarzyści, którzy chcieli zastąpić wino wodą w eucharystycznej ofierze, sądząc, że jest ono złe samo w sobie, a ponadto jest owocem Zlego ${ }^{18}$. W III-IV stuleciu przyjmują tę błędną naukę manichejczycy i komunikują tylko pod jedną postacią chleba ${ }^{19}$. W V wieku zdarzały się z kolei wypadki okazywania przez wiernych niechęci wobec Komunii pod postacią wina. To unikanie kielicha eucharystycznego przez chrześcijan ułatwiło manichejczykom - odrzucającym wino - komunikowanie pod postacią chleba w kościołach katolickich ${ }^{20}$. Na te fakty zareagował najpierw papiez Leon Wielki (440-461), który podstępne postępowanie manichejczyków potępił, określając jako świętokradzka symulację - sacrilega simulatio $^{21}$, a następnie nakazał wiernym w 445 roku komunikować pod dwiema postaciami, aby w ten sposób zdekonspirować niewiernych i wylączyć ich ze wspólnoty22.

W tej sytuacji Komunia pod dwiema postaciami stała się w sensie ścisłym sprawą ortodoksji, a w nauczaniu Kościoła daje się zauważyć dezaprobatę Komunii pod postacią chleba. W ten sposób Komunia sub utraque specie stawała się powszechną i była znakiem prawowierności. Toteż mając na uwadze godne i pobożne jej przyjmowanie oraz pragnąc zaradzić i zapobiec ewentualnym naduży-

${ }^{15} \mathrm{G}$. Mariani, La storia della comunione eucaristica, w: A. Piolanti, Eucaristia il mistero dell'altare, Roma 1957, s. 849-850.

${ }^{10}$ Por. Pius XII, Encyklika Mediator Dei, AAS 39 (1947) 552.

${ }_{17}$ J. Mielczarek, Komunia pod dwiema postaciami.., dz. cyt., s. 19.

${ }^{18}$ Tamże.

${ }^{19}$ L. Einsenhofer, Handbuch der katolischen Liturgik, t. II, Freiburg 1933, s. 312.

${ }^{20}$ Tamże, s. 312-313.

"Leon Wielki, Sermo 42, c. 5. PL LIV, 279 B-280 A.

22 Leon Wielki, Mowy, w: Pisma Ojców Kościoła, t. XXIV (przełożył K. Tomczyk) Poznań-Warszawa -Lublin 1958, s. 189-190. 
ciom, szukano praktycznych i dogodnych rozwiązań w jej udzielaniu. Wprowadzono wówczas, a było to około VII wieku, szczególnie w Rzymie, rurkę (fistula, calamus, pugillaris) do picia $z$ kielicha oraz praktykę bizantyjską - zanurzenie (per intinctionem) ${ }^{23}$.

Wobec zaniku praktyki Komunii wśród wiernych w wieku IV, Kościół musiał określić minimalny obowiązek jej przyjmowania, co czyniły synody prowincjalne i diecezjalne różnych krajów, a szczególnie sobór Laterański IV. Sobór ten nałożył obowiązek przyjmowania Komunii przynajmniej raz $\mathrm{w}$ roku w okresie paschalnym, a więc wtedy kiedy rozważamy w sposób szczególny tajemnicę śmierci i zmartwychwstania Chrystusa, czego uobecnieniem jest Eucharystia $^{24}$. Od tego czasu pojawil się prawny obowiązek Komunii wielkanocnej. Soborowe zarządzenie $\mathrm{i}$ inne spowodowały, że wierni trzy lub dwa razy, albo też raz w roku przystępowali do Komunii świętej. Trzeba było wtedy przygotować i zakonsekrować odpowiednią ilość wina, aby starczyło wszystkim komunikującym. Wtedy to pojawiły się spotkane już w V wieku specjalne kielichy, zwane ministerialnymi (calices ministeriales) ${ }^{25}$.

Mimo jednak prób innowacji (rurka, zanurzenie, specjalne kielichy) w sposobie przyjmowania drugiej postaci eucharystycznej, nie zdołano powstrzymać narastającej tendencji do unikania przez wiernych Komunii kielicha. Przyczyny tego zjawiska były niewątpliwie liczne i różnorodne, szczególnie zaś narastająca w XII wieku cześć do świętych Postaci, licznie przystępujący do Komunii wielkanocnej i przedłużanie się czasu udzielania Komunii, względy higieniczne, zdrowotne i fizjologiczne, trudność utrzymania przez dłuższy czas wina dla chorych, wreszcie względy praktyczne. ${ }^{26}$

Należy zauważyć, że zmiana w rycie Komunii dokonywała się w okresie szczególnie ożywionych rozważań teologicznych o Eucharystii i specyficznie wzmożonego zycia eucharystycznego wiernych. Spory teologiczne w XI i XII stuleciu koncentrowały się wokól rzeczywistej obecności Chrystusa pod postacią chleba i wina. Przyczyną tych kontrowersji były błędne teorie. Największy rozgłos

\footnotetext{
${ }^{23}$ J. Mielczarek, Komunia pod dwiema postaciami..., dz. cyt., s. 21.

${ }^{24}$ Conc. Lat. IV, c. 21. Concilionum Oecumenicorum Decreta..., dz. cyt., s. 245; Zob. Sakramenty wtajemniczenia chrześcijańskiego..., dz. cyt., s. 430-431.

${ }^{25}$ Tamze, s. 22.

${ }^{26}$ Tamże, s. 23-24.
} 
i zasięg uzyskała nauka Berengariusza z Tours († 1088), który zaprzeczył substancjalnej przemianie chleba $\mathrm{i}$ wina w Ciało I Krew Chrystusa, a opowiadal się za koncepcją symboliczno-spirytualistyczną. Według niego w Komunii przyjmujemy Chrystusa nie w sposób rzeczywisty lecz tylko myślą, gdyż Eucharystia, choć jest sakramentem Ciała i Krwi Chrystusa, nie zawiera ciała i krwi w sposób realny. Polemika spowodowana wystąpieniem Berengariusza przyczyniła się do wysunięcia na pierwszy plan w rozwoju nauki o Eucharystii kwestii rzeczywistej obecności Chrystusa w tym sakramencie ${ }^{27}$. Doktrynalne rozstrzygnięcie w tej sprawie dał dopiero sobór Lioński II (1274), orzekając o rzeczywistej obecności Chrystusa pod postaciami chleba i wina na drodze transsubstancjacji ${ }^{88}$. Wcześniej aż sześć synodów prowincjalnych w latach 10501074 za pontyfikatu czterech papieży potępiło naukę Berengariusza o Eucharystii2 ${ }^{29}$.

Od XI wieku wskutek herezji Berengariusza zaczął się silniej rozszerzać kult Eucharystii w formie adoracji, a zanikać - jak to powiedziano wcześniej - rozumienie Mszy świętej jako ofiary. W pobożności eucharystycznej wiernych następowało zjawisko zwrócenia prawie że wylącznej uwagi kultowej na Hostię. Był to proces paralelny do odsuwania się szczególnie od Komunii kielicha, a nawet od Komunii w ogóle, w tradycyjnym praktykowaniu i rozumieniu ${ }^{30}$. Pragnienie ludu, a nawet ządanie kapłanów, by ukazywali mu Hostię w czasie Mszy świętej, stało się przyczyną wprowadzenia na przełomie XIII i XIV wieku podniesienia Ciała Pańskiego. Przyjęcie się nowego zwyczaju ulatwilo przekonanie, że samo patrzenie na Hostię w czasie Mszy świętej zastępuje jej przyjmowanie i sprawia te same skutki duchowe, co komunikowanie postaci chleba ${ }^{31}$.

Wprowadzenie praktyki tzw. kielicha ablucyjnego z niekonsekrowanym winem, gdy wierni przyjmowali Eucharystię pod postacią chleba, było pewnym kompromisem w rycie komunikowania i zarazem przejściem do zwyczaju przyjmowania wyłącznie postaci chle-

"7 Tamże, s. 24.

${ }^{28}$ Denzinger 860 .

${ }^{29}$ K. Journet, Msza święta. Obecność Ofiary Krzyżowej, Poznań-Warszawa-Lublin 1959, s. 187, 339, 343.

.3. J. Mielczarek, Komunia pod dwiema postaciami..., dz. cyt., s. 24.

${ }^{31}$ Tamże, s. 24-25. 
$b^{32}$. Wielu autorów uważa, że w średniowiecznym Kościele łacińskim Komunia wiernych pod dwiema postaciami wychodzi ze zwyczaju głownie $z$ racji natury praktycznej, a nie dogmatycznej ${ }^{33}$. Ponadto świadomość, że kapłan komunikuje w zastępstwie wiernych (pro omnibus) coraz bardziej oddalała kielich od tych ostatnich, stawał się on przywilejem sprawującego ofiarę Mszy świętej. Jednocześnie do wzmocnienia takiego przekonania wiernych i równocześnie do rychłej powszechnej zmiany obrzędu komunikowania przyczyniły się ówczesne rozważania teologiczne Anzelma z Canterbury (1033-1109), Iwo z Chartes $(\dagger 1115)$, Alberta Wielkiego $(\dagger 1280)$, Tomasza z Akwinu (1225-1274), Aleksandra z Hales († 1245), którzy podkreślali i dowodzili, że w sakramencie ołtarza pod każdą postacią obecny jest cały Chrystus ${ }^{34}$. Nauka o konkomitancji, dająca teologiczną gwarancję, że się nie traci żadnej łaski, jeśli nie przyjmuje się kielicha, usunęła ostatecznie argumenty za utrzymaniem Komunii wiernych pod postacią wina. Skoro więc Chrystus jest cały obecny pod postacią chleba, po co więc narażać Eucharystię na profanację lub stwarzać inne niebezpieczeństwa.

Tak więc, na drodze zwyczaju Komunia pod jedną tylko postacią, która do tej pory była wyjątkiem, stała się już w XIII wieku zasadą i odwrotnie, Komunia pod dwiema postaciami, najpierw zwyczajna, pozostała tu i ówdzie jako praktyka wyjątkowa. Powstający w ten sposób zwyczaj i praktyka nie napotykały na sprzeciw ze strony urzędowej władzy kościelnej, a raczej były milcząco aprobowane ${ }^{35}$. W XIV stuleciu Komunia pod dwiema postaciami nie miała juz właściwie żadnych obrońców i nie pojawia się prawie nigdzie w praktyce $u$ wiernych ${ }^{36}$. Tak oto praktyka Komunii utrakwistycznej zachowała się w Kościele przez ponad tysiąc lat. Do dziś natomiast przetrwała w Kościołach wschodnich ${ }^{37}$.

Wzmożony kult Eucharystii na przełomie XII i XIII wieku - jak już podkreślono - nie wpłynął na przyjmowanie przez wiernych Komunii świętej. W okresie tym dawało się jednocześnie zauważyć, iż ze słabszą częstotliwością komunikowania przez wiernych, zanikała

\footnotetext{
${ }^{32}$ W. Spikowski, Ablucja w liturgii, w: Encyklopedia Katolicka, t. 1, Lublin 1973, s. 19.

${ }^{3}$ J. Mielczarek, Komunia pod dwiema postaciami..., dz. cyt., s. 23.

${ }^{34}$ Tamże, s. 25; W. Schenk, Liturgia sakramentów świętych, cz. I, Lublin 1962, s. 102-103.

${ }^{33}$ Tamże, s. 103.

3. J. Mielczarek, Komunia pod dwiema postaciami.., dz. cyt., s. 26.

"E. Przekop, Sakramenty święte w prawie Kościolów Wschodnich, Lublin 1979, s. 54.
} 
Komunia kielicha, co jednak nie spowodowało obniżenia się poziomu życia eucharystycznego, które wyrażało się teraz mocniej w adoracji Najświętszego Sakramentu. Ta forma pobożności eucharystycznej, nie napotykając na żadne przeszkody, rozwijala się do końca XIV stulecia. Do tego też czasu prawie całkowicie ustała praktyka Komunii świętej pod dwiema postaciami.

Już jednak w XIII wieku, w okresie spontanicznego i powszechnego zanikania Komunii kielicha wiernych w Kościele rzymskim pojawiły się głosy krytyki nowej praktyki ze strony obrządków Wschodnich ${ }^{38}$. Nabierały one na sile szczególnie w wieku XV. Nazwano je sporami o kielich eucharystyczny dla osób świeckich, a problem dostępu świeckich do kielicha stał się przedmiotem ostrych polemik religijno-politycznych ${ }^{39}$. Żądania kielicha szczególnie mocno akcentowali wtedy husyci i kalikstyni opierając się na zdaniu z ewangelii św. Jana: Jeśli nie będziecie spożywali Ciała Syna Czlowieczego i nie będziecie pili Krwi Jego, nie będziecie mieć życia w sobie ${ }^{40}$, a później w wieku XVI wznowili je protestanci, a nawet niektórzy katolicy, a co silnych echem odbiło się także w ówczesnej Polsce ${ }^{41}$.

W celu położenia kresu sporom Sobór w Konstancji na sesji XIII 15 czerwca 1415 roku wydal dekret o Komunii pod dwiema postaciami (potwierdzony przez papieża Marcina $\mathrm{V}-1$ września 1425 roku), w którym odrzucit jako błąd twierdzenie, że lud chrześcijański powinien przyjmować sakrament Eucharystii pod dwiema postaciami oraz uzasadnił słuszność praktyki rozpowszechnionej w Kościele, jako mającej powagę obowiązującego prawa ${ }^{42}$.

\footnotetext{
${ }^{3 .}$ J. Mielczarek, Komunia pod dwiema postaciami.., dz. cyt., s. 27.

${ }^{39}$ Sakramenty wtajemniczenia chrześcijańskiego..., dz. cyt., s. 346-347; Zob. W. Urban, W sprawie Komunii pod dwiema postaciami w diecezji wroctawskiej, Collectanea Theologica 39 (1969) 77.

40 J 6, 53;

${ }^{41}$ W. Urban, W sprawie Komunii pod dwiema postaciami..., art. cyt., s. 77.

${ }^{42}$ Conc. Constantiense, sess. XIII, Decretum Cum in nonnullis:... chociaż w pierwotnym Kościele wierni przyjmowali ten sakrament pod obiema postaciami, jednakze $w$ celu uniknięcia pewnych niebezpieczeństw i zgorszenia, zostal wprowadzony ten rozumny zwyczaj, że kaptani sprawujacy Msze święta przyjmuja pod obiema postaciami, świeccy zaś tylko pod jedna postaciq chleba. Należy bowiem mocno wierzyć i nie dopuszczać wątpliwości, ze cale Cialo i Krew Chrystusa znajduje się prawdziwie tak pod postacia chleba jak pod postacia wina. Ponieważ więc ten zwyczaj w sposób rozumny zostal wprowadzony przez Kościót i przez świętych ojców i ponieważ bardzo dlugo byl zachowywany, należy go uwazać za prawo, którego nie wolno odrzucic, ani bez upoważnienia Kościota samodzielnie zmieniać. Dlatego też twierdzenie, że ten zwyczaj albo zachowanie tego prawa sq swiętokradzkie
} 
Walka $\mathrm{z}$ utrakwizmem na forum soboru w Konstancji i w literaturze polemicznej okazała się bezskuteczna. Jedynym jej następstwem było ukształtowanie się i skonsolidowanie zwalczających się stron. Rozgorzały wojny husyckie o charakterze religijnym, społecznym i narodowościowym, a na ich sztandarach widniał kielich eucharystyczny. Na zbrojne prowokacje husytów, obóz katolicki odpowiadał kolejnymi krucjatami. ${ }^{43}$ Naprzeciw tym tendencjom wyszedł sobór w Bazylei, który w roku 1437 dopuścił możliwość Komunii pod dwiema postaciami w Czechach, potwierdzając i utrzymując powszechna praktykę komunikowania pod jedną postacią jako zgodną z prawem Kościoła, którą można było zmieniać tylko z jego upoważnienia ${ }^{44}$.

Zdecydowane stanowisko doktrynalne w sprawie Komunii pod dwiema postaciami zajął sobór Trydencki podczas sesji XXI i XXII. Na wcześniejszej sesji - XIII, Sobór określając naukę o Eucharystii, która stanowiła jedną z zasadniczych kontrowersji w dobie reformacji, przedstawił problem obecności Chrystusa pod postaciami eucharystycznymi i Komunii wiernych. Sobór nie podał nowej doktryny o Eucharystii, ale przedstawił tradycyjną naukę, jaką wypracowano przede wszystkim w wieku XII i XIII. Zasady odnoszące się do Komunii pod dwiema postaciami, przyjęte i ogłoszone przez Tridentinum, można określić jako dogmatyczno-prawne ${ }^{45}$, zawierały bowiem następujące wskazania:

1. Komunia pod jedną postacią wystarcza do zbawienia;

2. Należy uznać, ze pod jedna postacią przyjmuje się w pełni calego Chrystusa i prawdziwy sakrament;

3. Komunikowanie pod jedną postacią jest wystarczająco owocne, ponieważ zapewnia wszystkie laski potrzebne do zbawienia;

4. Ani $z$ ustanowienia Chrystusa, ani z innych tekstów biblijnych nie wynika nakaz czy też obowiązek przyjmowania Komunii świętej pod obiema postaciami przez świeckich oraz przez duchownych nie celebrujących;

lub niegodziwe, jest btędem, a ci którzy tak utrzymuja, winni być uznani za heretyków". Tłumaczenie podana za: Sakramenty wtajemniczenia chrześcijańskiego..., dz. cyt., s. 347; Por. Denzinger 626; Concilionum Oecumeniconum Decreta..., dz. cyt., s. 418-419.

${ }^{43} \mathrm{~J}$. Mielczarek, Komunia pod dwiema postaciami..., dz. cyt., s. 67.

${ }^{4} \mathrm{~K}$. A. Fink, Das Konzil von Konstanz. Martin V, w: Handbuch der Kirchengeschichte, t. III, Freiburg 1968, s. 576; Zob. Mansi XXIX, 158.

${ }^{4}$ Conc. Trid., sess. XXI, c. 1-3, Doctrina de communione; Zob. Concilionum Oecumeniconum Decreta..., dz. cyt., s. 693-695. 
5. Kościól posiada władze określania i zmiany sposobu szafowania sakramentów pod warunkiem, że zmiana nie dotyczy istoty sakramentu lecz jego elementów akcydentalnych (miejsca, czasu, pożytku przyjmujących, czci sakramentu);

6. Kościól zwyczajowi komunikowania pod jedną postacią nadaje charakter prawa;

7. Tego prawomocnego zwyczaju komunikowania nie wolno ganić, ani bez powagi Kościoła dowolnie zmieniaćc ${ }^{46}$.

Przyjęte przez Sobór kanony, mające charakter anatem, przez swoją formę stanowily istotne normy dogmatyczne i prawne w sprawie nauki i dyscypliny Kościoła o Komunii pod dwiema postaciami. Stanowisko soboru Trydenckiego w kwestii praktycznej - czy na przyszłość należy dopuścić udzielanie Komunii pod dwiema postaciami czy też go odmówić - było nacechowane niemałym wahaniem. Sprawa byla dyskutowana podczas XXI sesji soborowej, ale nie zostala rozstrzygnięta ${ }^{47}$. Również debata podczas następnej sesji nie doprowadziła do rozstrzygającej decyzji Soboru. Ostatecznie Sobór postanowil pozostawić sprawę do uznania papieża. Postanowienie to zostało wyrażone w Decretum super petitione concessionis calicis sformułowanym podczas XXII sesji soborowej ${ }^{48}$.

W myśl tego dekretu papież Pius IV ( $†$ 1565) w dniu 16 kwietnia 1564 roku upoważnił metropolitów Moguncji, Kolonii, Trewiru, Wiednia, Pragi, Salzburga i Ostrzychomia do udzielania zezwolenia na udzielanie i przyjmowanie Komunii pod dwiema postaciami. Był to tzw. indult kielicha - czasowe zezwolenie odnoszące się do Niemiec, Austrii, Węgier i Czech ${ }^{49}$. Podobnej koncesji, czyli upoważnienia i pozwolenia na udzielanie i przyjmowanie Komunii pod dwiema postaciami udzielono 26 lipca 1564 roku dla Wrocławia i Śląska ${ }^{50}$. Po-

\footnotetext{
th Zob. S. Frankl, Decretum Tridentinum de communione sub utraque specie, Collectanea Theologica 18 (1937) s. 552-572.

${ }^{47}$ Zob. Conc. Trid., sess. XXI, c. 1-3, Canones de communione sub utraque specie; Zob. Concilionum Oecumenicorum Decreta..., dz. cyt., s. 694-695.

${ }^{45}$ Conc. Trid., sess. XXII, Decretum super petitione concessionis calicis; Zob. Conciliorum Oecumeniconum Decreta..., dz. cyt., s. 941.

${ }^{49}$ Sakramenty wtajemniczenia chrześcijańskiego..., dz. cyt., s. 349; Zob. J. Mielczarek, Komunia pod dwiema postaciami..., dz. cyt., s. 131-132.

") F. Kokoszka. Communio sub utraque specie na Ślqsku w wieku XVI, Prawo Kanoniczne 10 (1967) nr 1-2, s. 357-373; Tenże, Komunia pod dwiema postaciami w katedrze wroctawskiej przy końcu XVI wieku, Homo Dei 34 (1965) s. 206-212; W. Urban, W sprawie Komunii pod dwiema postaciami..., art. cyt., s. 80.
} 
nieważ jednak kielich eucharystyczny stał się wówczas znakiem odróżniajacym wyznania - katolików od protestantów, przywileje i pozwolenia spotykaly się ze sprzeciwem ludności katolickiej, w rezultacie czego papież Grzegorz XIII ( $\dagger$ 1585) w roku 1584 odwolal udzielone indulty. Zakaz udzielania Komunii pod dwiema postaciami został ponowiony w roku $1604 \mathrm{w}$ odniesieniu do Węgier, a w roku 1621 w odniesieniu do $\mathrm{Czech}^{51}$. W katedrze wrocławskiej korzystano $\mathrm{z}$ indultu do roku $1597^{52}$. Stosunkowo dłuzej pozwolenie to dotyczyło Śląska, gdzie ruch rekatolizacji nie był tak silny. Tutaj dopiero dekret kancelarii cesarskiej z 22 lipca 1624 roku odwolał przywilej Komunii sub utraque specie, nakazując powrót do praktyki pod jedną postacią ${ }^{53}$. Ze strony Kościoła została ona formalnie zniesiona przez Stolicę Apostolską za pośrednictwem nuncjusza, który kapitule wrocławskiej przedstawił (31 sierpnia 1628 roku) dekret $z$ dnia 23 sierpnia 1628 roku żądający całkowitego zniesienia używania kielich ${ }^{54}$.

Należy zauważyć, iż ważną rolę w wyjaśnianiu nauki Tridentinum, w tym dyscypliny Komunii pod jedną postacią, odegrał Katechizm Trydencki, zatwierdzony przez papieża Piusa V (1566-1572), który ukazał się we wrześniu $1566 r{ }^{55}$ Bezpośrednimi adresatami tego podręcznika byli proboszczowie, którym przede wszystkim należało wyjaśniać naukę Soboru, aby mogli z przekonaniem przestrzegać dyscypliny Komunii pod jedna postacią dla świeckich. Katechizm Trydencki dostarczyl zatem treści i argumentów do stosownego pouczania wiernych o słuszności i pełnej wartości przyjmowanej przez nich Komunii tylko pod postacią chleba.

Kościół katolicki określając na Soborze Trydenckim naukę i praktykę dotyczącą Komunii jednocześnie stwierdzil, że tylko on, własną powaga i autorytetem, może w tej materii dokonywać stosownych i prawomocnych innowacji. Wyraźnym dowodem kompe-

"Sakramenty wtajemniczenia chrześcijańskiego..., dz. cyt., s. 349.

s: W. Urban, W sprawie Komunii pod dwiema postaciami..., art. cyt., s. 80.

${ }^{53} \mathrm{~J}$. Mielczarek, Komunia pod dwiema postaciami..., dz. cyt., s. 136.

${ }^{54}$ F. Kokoszka, Communio sub utraque specie..., art. cyt., s. 372; Tenże, Komunia święla pod dwiema postaciami w katedrze wroclawskiej przy końcu XVI wieku..., art. cyt., s. 212; W. Urban, W sprawie Komunii pod dwiema postaciami..., art. cyt., s. 80.

${ }^{53}$ Catechismus ex decreto Concilii Tridentini ad parochus Pii V. Pontificis Max. Et deinde Clementis XIII iussu editus. Taurini-Romae 1924, nr 65-66, s. 226-228; Zob. Katechizm Rzymski wediug uchwaty św. Sobonu Trydenckiego dla plebanów ulożony, z rozkazu najprzód Piusa $V$, potem Klemensa XIII, na polski jezyk w lat cztery po Soborze przez ks. Walentego Kuczborskiego przetlumaczony, t. I-III, Jasło 1866. 
tencji Kościoła było udzielenie pozwolenia w roku 1564 przez papieza Piusa IV na kielich dla świeckich na terenie krajów niemieckich, a także późniejsze decyzje o wycofaniu tej koncepcji. Po tym nieudanym eksperymencie przez cztery następne stulecia zwyczajną i powszechną praktyką będzie Komunia tylko pod jedną postacią, tj. chleba, co było wyraźną wolą Tridentinum w obliczu przeciwnego zwyczaju innowierców. Jednakże $w$ tym okresie istniały nadal, nieliczne wprawdzie, przypadki korzystania $z$ Komunii pod obiema postaciamis ${ }^{56}$.

Sprzyjające warunki i okazję do rozważenia ewentualnego powrotu w Kościele zachodnim do Komunii pod dwiema postaciami stworzył w połowie XX wieku ożywiony ruch ekumeniczny i proces odnowy liturgicznej. W ośrodkach liturgicznych sprawa kielicha była dojrzała do dyskusji, a wynikała przede wszystkim z głębokiego umiłowania świętej liturgii Kościoła i stawała się ważnym elementem zjednoczenia chrześcijan ${ }^{57}$. Naprzeciw tym tendencjom i oczekiwaniom wyszedł Sobór Watykański II. Sobór ten, zachowując zasady dogmatyczne ustalone przez Sobór Trydencki, postanowil, że w przypadkach określonych przez Stolicę Apostolską biskupi mogą zezwalać na Komunię świętą pod dwiema postaciamis ${ }^{58}$ Sytuacje

\footnotetext{
${ }^{56}$ Problem Komunii pod dwiema postaciami pojawil się ponownie w ustawodawstwie kościelnym glównie na plaszczyźnie międzyobrządkowej. Komunia pod obiema postaciami byla udzielana we wschodnich Kościolach katolickich. Niektóre obrządki z czasem odstąpily od tej powszechnej dyscypliny. Co więcej, do XVIII wieku nie istniał w Kościele żaden przepis, który by zakazywał katolikom jednego obrządku komunikować $w$ innym obrządku. Powodowało to pewnego rodzaju zamieszanie. Dopiero papież Benedykt XIV konstytucją Etsi pastoralis z 26 maja 1742 r. stworzył nowe prawo międzyobrządkowe, w którym zabronił - poza wypadkami konieczności - przyjmować Komunię w obcym obrządku. Dyscyplinę tę nieco złagodził Pius X zapewniając wiernym wolność przyjmowania Komunii z pobożności w jakimkolwiek obrządku katolickim. Z generalnej zasady zostala wylączona Komunia wielkanocna i wiatyk.

$\mathrm{Na}$ mocy zwyczaju lub przywileju w niektórych miejscach i przy niektórych obrzędach liturgicznych także utrzymywała się nadal Komunia pod dwiema postaciami tak dla świeckich, jak i dia duchownych celebrujących Mszę święta. Np. królowie Francji mieli przywilej Komunii pod obiema postaciami, w czasie Mszy koronacyjnej i na łożu śmierci; taki przywilej miał również cesarz niemiecki Franciszek II; diakoni i subdiakoni w kościele St. Denis w Paryżu. Wyjątki te uznawali papieże i Stolica Apostolska, nie wyrażając jednak zgody na przyjmowanie Komunii pod dwiema postaciami przez tych, którzy o taki indult prosili. Mimo to, w niektórych środowiskach Komunia kielicha dla świeckich nadal wzbudzała zainteresowanie, a jego pragnienie nigdy całkowicie nie zniknęlo. J. Mielczarek, Komunia pod dwiema postaciami..., dz. cyt., s. 137-138 i 140-145.

${ }^{57}$ Zob. M. J. Charles, La Communion au calise, La Maison-Dieu 85 (1966) s. 168-177.

${ }^{58} \mathrm{KL} 55$.
} 
i okoliczności w których możliwe jest udzielanie Komunii pod postacią chleba i wina określają dokumenty posoborowe Stolicy Apostolskiej, na które - pozwalając na Komunię pod dwiema postaciami - powołuje się ustawodawca kodeksowy w kan. $925^{59}$.

\section{Regulacje polskiego ustawodawstwa synodalnego}

Ukazana dyscyplina i praktyka komunikowania w prawie powszechnym Kościoła katolickiego odnosiła się także do Polski. Regulacje i ustalenia prawne w tym względzie podejmowały synody prowincjalne i diecezjalne. Ich statuty synodalne i inicjatywy poszczególnych biskupów, na bazie ustawodawstwa powszechnego, podejmowały trud wdrażania tego prawa i dyscypliny odnośnie sposobu komunikowania w życie Kościoła w Polsce, które - tak jak życie i praktyka Kościola powszechnego w tym względzie - wymagało regulacji. Należy zauważyć, że ustawodawstwo to musiało brać pod uwagę narastające tendencje i żądania Komunii utrakwistycznej głoszone przez różnych „,reformatorów” na gruncie polskim, takich między innymi jak: Andrzeja Frycza Modrzewskiego, Stanisława Orzechowskiego i innych zwolenników Komunii kielicha. Żądania te były połączone ze swoistym pędem tego okresu do zreformowania stosunków religijnych w Polsce. Można powiedzieć, iż wołanie o Komunię sub utraque specie było częścią wielkiego wołania o reformę Rzeczypospolitej, rozwijającej się pod wpływem humanizmu i reformacji.

Określając sposób udzielania Komunii świętej ustawodawcy synodalni najwięcej miejsca poświęcali zanoszeniu Eucharystii chorym. Pewne nieporozumienie w aspekcie omawiania Komunii pod dwiema postaciami budzi zapis rozdziału 116 statutów synodu legata Filipa Firmeńskiego z 1279 r., w którym ustawodawca synodalny mówił dokładniej o naczyniach świętych używanych przy zanoszeniu wiatyku, a na który powoływali się później ustawodawcy synodalni ${ }^{60}$. Otóż legat papieski nakazał, aby najpóźniej do Wielkanocy wszyscy proboszczowie i rektorzy kościołów parafialnych, pod groź-

\footnotetext{
${ }^{99}$ Zob. T. Pawluk, Prawo kanoniczne wedlug Kodeksu Jana Pawla II..., dz. cyt., t. II, s. $388-390$.

${ }^{60}$ Philipus Firmanus Episcopus Legatus, Synodus Budensis a. 1279, cap. 116. R. Hube, Antiquissimae Constitutiones Synodales Provinciae Gnesnensis, maxima ex parte nunc primum e condicibus manu scriptis typis mandatae, Petropoli 1856, s. 155.
} 
bą suspensy, zaopatrzyli się w specjalne kielichy do komunikowania chorych. Kontrowersje i niezrozumienie budzi równoczesne użycie w zapisie tego rozdzialu wyrażenia kielich do komunikowania chorych i puszka do niesienia Ciata Pańskiego, sugerujące używanie dwóch naczyń liturgicznych w celu udzielania Komunii chorym pod dwiema postaciami. Otóż zamieszczenie tych określeń w kontekście nakazu sprawienia przez proboszczów i rektorów kościołów nowych kielichów do wiatyku i wzmianka o puszkach jako przedmiotach liturgicznych już posiadanych, należy rozumieć tak, że na czas drogi do chorego wkładano mały kielich z Najświętszym Sakramentem do zamykanej puszki celem zabezpieczenia Eucharystii przed przypadkową zniewagą. Za taką interpretacją zapisu statutu synodu legackiego, przemawia używanie na Zachodzie tzw. calix viaticus (wysoki 6-9 centymetrów) do zanoszenia Komunii chorym. Natomiast wykluczone wydaje się być na podstawie tekstu przypuszczenie o posługiwaniu się dwoma naczyniami liturgicznymi do udzielania wiatyku pod dwiema postaciami ${ }^{61}$.

Idea Komunii sub utraque specie nie stanowila w Polsce novum, gdyż była zaszczepiona już przez ruch husycki w XV wieku. Nadto promieniowanie praktyki utrakwistycznej w znacznym stopniu ułatwil fakt - jak to zaznaczono wyżej - udzielania Komunii pod dwiema postaciami na Śląsku, którzy należal do Polski. Jednocześnie Kościół prawosławny, podobnie jak i Kościól ormiański komunikował pod dwiema postaciami ${ }^{62}$. W tej sytuacji także wśród katolików pojawily się głosy żądające Komunii pod dwiema postaciami. Już w 1374 roku rozszerzali naukę o Komunii utrakwistycznej w Polsce Maciej z Janowa i były kanonik praski Jan Milicz. Jarosław arcybiskup gnieźnieński nie zakazał tego nauczania, za co upomniał go papież Grzegorz XI' ${ }^{63}$.

Pierwszym bardzo ważnym śladem polskiego ustawodawstwa synodalnego w odniesieniu do udzielania Komunii pod jedną postacią chleba jest synod chelmski biskupa Jana Biskupca z 1440-1441 roku. W uchwałach tego synodu, w części czwartej statutów, znaj-

\footnotetext{
${ }^{6} \mathrm{~W}$. Wójcik, Wiatyk w średniowiecznym ustawodawstwie biskupów polskich, Ruch Biblijno-Liturgiczny 6 (1953) s. 122.

${ }_{62} \mathrm{~J}$. Mielczarek, Komunia pod dwiema postaciami..., dz. cyt., s. 142.

${ }^{3} \mathrm{P}$. W. Fabisz, Wiadomość o legatach $i$ nuncjuszach apostolskich $w$ dawnej Polsce (1075-1863), Ostrów 1864, s. 69.
} 
dujemy głęboko rozbudowany traktat apologetyczny skierowany przeciwko nauce husytów, dotyczący sprawy Komunii pod dwiema postaciami ${ }^{64}$. Był to zapewne rezonans soborowego dekretu Cum in nonnullis z 1415 roku. W traktacie zatytułowanym Sequitur de communione Venerabilis Sacramenti ustawodawca synodalny wykładał i przybliżał duchowieństwu i wiernym naukę Kościoła o Eucharystii, a szczególnie o Komunii utrakwistycznej w czterech tezach:

1. Udzielanie wiernym świeckim Komunii pod dwiema postaciami sprzeczne jest z wolą Jezusa Chrystusa;

2. Ta forma komunikowania sprzeczna jest $z$ duchem Pisma świętego;

3. Sprzeczna jest z postanowieniami Ojców i Doktorów Kościoła;

4. Sprzeczna jest ze statutami i dekretami Kościoła rzymsko-katolickiego, który ma prawo orzekać o tym, czego ludzie świeccy w przedmiocie wiary i sakramentów świętych mają przestrzegać.

Jednocześnie przytaczając cytaty z Pisma świętego i Ojców Kościoła ustawodawca synodalny wzywał kaplanów, aby nie tolerowali wśród wiernych błędnej nauki komunikowania pod obiema postaciami oraz strzegli czystości nauki katolickiej. Na każdą z wyżej przytoczonych tez, biskup jako ustawodawca synodalny, przeprowadzał obszerny dowód w oparciu o Pismo święte, Ojców Kościoła i powszechne prawo kościelne ${ }^{65}$.

Traktat ten, a może nawet i podręcznik, którego autorem był biskup Jan Biskupiec należy uznać za zjawisko wyjątkowe i bardzo interesujące w polskim ustawodawstwie synodalnym. O ile bowiem dotąd wiemy, żaden z polskich biskupów, oprócz biskupa Bernarda Maciejowskiego i jego Pastoralnej ${ }^{66}$, nie zdobył się na podobny podręcznik dla swego duchowieństwa, zaprezentowany na synodzie diecezjalnym, a więc uznany za obowiązujący i promulgowany w specjalnie uroczystej formie. Nie jest przypadkiem, że dziela tego dokonał

\footnotetext{
${ }^{64}$ J. Sawicki, Concilia Poloniae. Źródla i studia krytyczne, t. IV, Najdawniejsze statuty synodalne diecezji chelmskiej $z X V$ wieku, Lublin 1948, s. 102-103.

${ }^{35}$ Synodus Chełmensis a. 1440-1441, tit. Sequitur de communione Venerabilis Sacramenti. J. Sawicki, Concilia Poloniae..., dz. cyt., t. IV, s. 195-206.

${ }^{\circ}$ Epistola Pastoralis bona memoria Illustrissimi Cardinales Macieiowski Itenum a Sacra Congregatione Illustrissim: Cardinalium S. Concilii Tridentini interpretatum, recognita et a SS. D. N. Urbano Papa VIII approbata. Nunc recens pro usu Cleri Dioecesis Posnaniensis cum licentia superiorum edita. Posnaniae in Officina Alberti Reguli, Anno Domini M. D. C. XXXX; Zob. S. Nasiorowski, „List pasterski” kard. Bernarda Maciejowskiego, Lublin 1992, s. 132-134.
} 
biskup dominikanin, wychowanek zakonu kaznodziejskiego, teolog, który troskę o czystość wiary uważał za swój pierwszy obowiązek ${ }^{67}$.

Wraz $z$ naplywem prądów reformatorskich do Polski żądania wprowadzenia Komunii pod dwiema postaciami wzmagały się. W kwietniu 1550 roku przybyła do króla Zygmunta II Augusta (1548-1572) delegacja z żądaniem kielicha dla świeckich, gdyby zaś tego żądania nie zaspokojono groziła, że szlachta przestanie płacić duchowieństwu dziesięciny ${ }^{68}$. Obok religijnych tendencji reformatorskich idących $\mathrm{z}$ zewnątrz, istniał jednocześnie swoisty pęd do zreformowania stosunków religijnych w Polsce. Był on częścią wielkiego wolania o reformę Rzeczypospolitej, obudzony i rozwijający się pod wpływem humanizmu i reformacji. Chciano usunąć przywileje duchowieństwa pod względem materialnym, spolecznym i politycznym. Domagano się udzielania Komunii pod dwiema postaciami, zniesienia bezżeństwa kaplanów i odprawiania nabożeństw w języku ojczystym. Myślano też o Kościele narodowym ${ }^{69}$.

W kontekście takich trendów o podobne pozwolenie na Komunię kielicha, jakie w 1564 roku uzyskały Niemcy, Austria, Węgry i Czechy, a także Wrocław i Śląsk - jak to wskazano wyżej - starała się również Polska, ale jeszcze wcześniej. Otóż już w roku 1556 udała się polska delegacja do papieża Pawła IV z prośbą, aby dozwolonym bylo komunikować pod obiema postaciami. Mimo, że petycja nie została uwzględniona, to jednak Polska zyskała wielu zwolenników. We wrześniu 1565 roku prymas Jakub Uchański pod pretekstem narady nad wprowadzeniem w życie i wykonaniem uchwał Soboru Trydenckiego, zwołal synod prowincjalny do Piotrkowa. W rozesłanym na synod piśmie (artykułach) znalazła się znamienna uwaga: ponieważ niedawno dla utrzymania pokoju zabroniono ustepstwa w rzeczach uznanych za stuszne, czy z jakiegokolwiek tytutu nasze kraje nie powinny zadać od Stolicy Apostolskiej takich rzeczy, które moglyby przyczynic się do trwalszego utrzymania wiernych przy Kościele katolickim ${ }^{70}$. Jednakże Polska nie doczekała się takiego przywileju, tym bardziej, że rodzić się począł

\footnotetext{
${ }^{67}$ J. Sawicki, Concilia Poloniae..., dz. cyt., t. IV, s. 103-104.

${ }^{68} \mathrm{~T}$. Wierzbowski, Jakub Uchański arcybiskup gnieźnieński, Warszawa 1895, s. 289.

${ }^{64}$ J. Bochenek, Stanisiawa Hozjusza nauka o Eucharystii, Warszawa 1936, s. 9-10.

${ }^{70}$ Cytowano za: S. Kot, Andrzej Frycz Modrzewski, Kraków 1923, s. 256; Por. L. Pankowski, Komunia pod dwiema postaciami w postulatach Andrzeja Frycza Modrzewskiego (mps) Lublin 1972, s. 43; H. D. Wojtyska, Polacy na soborze Trydenckim, Roczniki Teologiczno-Kanoniczne 15 (1968) z. 4, s. 100.
} 
w Kościele klimat niesprzyjający Kielichowi. Chociaż i w Polsce idea Komunii utrakwistycznej nie pozostawała bez echa.

Programową rozprawą o reformie w Polsce było dzieło Andrzeja Frycza Modrzewskiego (ok. 1503-1572) Commentarium de Republica emendanta wydane w 1551 i 1554 roku w Bazylei ${ }^{7 !}$. Pisał on: Nie walczymy tu o postacie komunikowania, jak sadza niektórzy, pisat Modrzewski - lecz o to, by ludziom świeckim udzielano w catości sakramentu Eucharystii [...]. Jeżeli tedy zblizajacy się Sobór będzie uwa$\dot{z}$ al, że wyjdzie to na korzyść godności religii, tatwo da sie naktonić do pozwolenia świeckim swobody przyjmowania tego sakramentu pod jedna postacia albo pod obiema postaciami ${ }^{72}$. Polski reformator nie odrzucał dotychczasowej praktyki Kościoła, a jedynie domagał się miejsca i tolerancji dla drugiego sposobu komunikowania i takiej decyzji oczekiwał od Soboru Trydenckiego.

Zasadniczym i wyczerpującym traktatem Modrzewskiego o kielichu dla świeckich był dialog o przyjmowaniu przez wiernych świeckich sakramentu ołtarza pod dwiema postaciami, spisany nie dla rozstrzygnięcia, ale dla dyskusji i pouczania się (1549) ${ }^{73}$.

$\mathrm{Z}$ poglądami Modrzewskiego polemizował kardynał Stanisław Hozjusz (1504-1579) w Wyznaniu wiary, w którym rozdział 39 omawiał wylącznie sprawy Komunii pod dwiema postaciami ${ }^{74}$. Jeszcze ostrzej zwalczał utrakwistyczne poglądy Modrzewskiego kardynał Hozjusz w traktacie Dialogus de eo num calicem laicis et uxores sacerdotibus permitti ac divina officina vulgari lingua peragi fas est wydanym w Dilindze w 1558 roku $^{75}$.

Drugim na gruncie polskim reformatorem był Stanisław Orzechowski (1513-1566), który również opowiadał się za Komunią pod dwiema postaciami ${ }^{76}$.

"A. Frycz Modrzewski, Dziela wszystkie, t. I, O prawie Rzeczypospolitej, Warszawa 1953; Por. M. Rechowicz, Teologia pozytywno-kontrowersyjna: szkola polska w XVI wieku. W: pr. zb. pod red. M. Rechowicza, Dzieje teologii katolickiej w Polsce, t. II, cz. 1. Lublin 1975, s. 51-52.

${ }^{n}$ A. Frycz Modrzewski, Dzieta wszystkie..., dz. cyt., t. I, s. 483; Por. J. Bochenek, Stanislawa Hozjusza nauka o Eucharystii..., dz. cyt., s. 15-18.

${ }^{73}$ S. Kot, Andrzej Frycz Modrzewski..., dz. cyt., s. 88-90.

${ }^{14}$ Confesio Fidei Catholica Authoritate synodi provincialis, que habita est Petricoviae a. 1551 mense Junio edita. Zob. S. Kot, Andrzej Frycz Modrzewski.., dz. cyt., s. 108.

${ }^{75}$. Hozjusz, Rozmowa o tym, godzi li się laikom kielicha, księzej żon dopuścić a w kościele stużbe Boża jezykiem przyrodzonym sprawować, Kraków 1562, s. 85-118; Por. J. Bochenek, Stanisława Hozjusza nauka o Eucharystii..., dz. cyt., s. 21-27.

${ }^{76}$ L. Pankowski, Komunia pod dwiema postaciami..., dz. cyt., s. 42. 
Na skutek narastających tendencji i żądań Komunii utrakwistycznej z ostrym sprzeciwem i dezaprobatą wypowiadały się na ten temat polskie synody diecezjalne, szczególnie w tych diecezjach, w których problem ten narastał i był aktualny. Synod przemyski biskupa Jana Dziaduskiego z 1554 roku w statucie siódmym wyraźnie zabraniał Komunii sub utraque specie, zalecając przeciwstawiać się jej stanowczo w kościelnym przepowiadaniu Słowa Bożego na podstawie tekstów Ewangelii, listu św. Pawla i nauki innych Apostolów oraz Doktorów Kościoła. Podobnie w statucie szesnastym synod nie dopuszczał możliwości Komunii pod dwiema postaciami lecz nakazywał wiernym świeckim przyjmować Komunię pod jedną postacią chleba, według dekretu soboru w Konstancji ${ }^{7}$.

Program reform zaprogramowanych przez Modrzewskiego został sprecyzowany na sejmie w 1555 roku. Uchwalono tam dziewięć postulatów, które przedstawiono królowi. Wśród nich trzeci głosił: wolno niech będzie sakrament Ciała i Krwi Pańskiej pod dwiema postaciami kazdemu, kto tego zażada, podawaç8.

$\mathrm{Na}$ żądanie sejmu Zygmunt August wysłał w 1556 roku do papieża kasztelana sandomierskiego Stanisława Maciejowskiego z prośbą jak to wspomniano wcześniej - o uzyskanie zgody od Stolicy Apostolskiej na cztery zasadnicze sprawy, a mianowicie aby: 1. Msza święta i inne nabożeństwa były sprawowane w języku polskim; 2. Wiernym świeckim udzielano Komunii świętej pod dwiema postaciami; 3. Księża mogli zawierać małżeństwa; 4. Polska miała możliwość zwołania synodu narodowego ${ }^{79}$. Papież, który $z$ niemalym smutkiem i goryczą stuchat tych żądań oświadczył, że powyższe żądania i postulaty zmuszają go do przyspieszenia zwołania soboru powszechnego, który uczyniłby zadość wszelkim słusznym wymaganiom ${ }^{80}$.

Odrzucenie przez Rzym petycji wzmoglo jeszcze bardziej polemikę i pchnęło wielu do praktykowania Komunii utrakwistycznej,

${ }^{7}$ Synodus Praemyslensis a. 1554 ( 7 i 16). J. Sawicki, Concilia Poloniae. Źródla i studia krytyczne, t. VIII, Synody diecezji przemyskiej obrzadku lacinskiego i ich statuty, Wroclaw 1955 , s. 165 i 167.

${ }^{78}$ W. Zakrzewski, Powstanie i wzrost reformacji w Polsce 1520-1572, Lipsk 1870, s. 80; J. Bochenek, s Stanislawa Hozjusza nauka o Euchanystii.., dz. cyt., s. 10.

${ }^{79}$ Tamże, s. 11; Zob. W. Zakrzewski, Powstanie i wzrost reformacji $w$ Polsce..., dz. cyt., s. 95.

${ }^{80}$ Tamże, s. 96; Por. B. Kumor, Protestancka reformacja na ziemiach polskich, w: $\mathrm{Hi}$ storia Kosciola w Polsce (pod red. B. Kumora, Z. Obertyńskiego) t. II, Poznań-Warszawa 1974 , s. 67. 
a idea zyskała poparcie w nawet niektórych kołach hierarchii kościelnej ${ }^{81}$.

Żądanie Komunii pod dwiema postaciami dla świeckich w oparciu o Pismo święte było pierwszym i ważnym postulatem katolików reformatorów w Polsce ${ }^{82}$. Znalazło ono swój oddźwięk w czasie obrad Soboru Trydenckiego w trzeciej jego fazie ${ }^{83}$, kiedy to Stanisław Falęcki - opat cystersów w Sulejowie aż czterokrotnie domagał się dla Polski Komunii utrakwistycznej ${ }^{84}$. Przeciwnego zdania był kardynał Stanisław Hozjusz, jeden z czterech legatów papieskich, który do końca był zdania, że Komunia pod dwiema postaciami nie daje przyjmującym więcej laski, niż pod jedną postacią, broniąc w ten sposób Komunii pod postacią chleba ${ }^{85}$.

Sobór Trydencki - jak już powiedziano - określając naukę i praktykę dotycząca Komunii stwierdził, że tylko on własną władzą i autorytetem, może w tej materii dokonywać stosownych i prawomocnych innowacji. Jednak soborowy dekret Decretum super petitione concessionis calicis sformulowany podczas XXII sesji soborowej, pozostawiający sprawę Komunii utrakwistycznej uznaniu papieża, nie dający definitywnego rozwiązania tego problemu i umożliwiający przyznawanie papieskich koncesji na Komunię pod dwiema postaciami, stał się nieudanym eksperymentem i spowodował, że przez cztery następne stulecia zwyczajną i powszechną praktyką będzie Komunia tylko pod jedną postacią, tj. chleba, co bylo wyraźną wolą soboru Trydenckiego w obliczu przeciwnego zwyczaju innowiercó $w^{86}$.

Uchwały Soboru Trydenckiego nalezało wprowadzić w życie Kościoła w Polsce. Nie było to łatwe w obliczu możliwości zwołania sy-

\footnotetext{
${ }^{81}$ L. Pankowski, Komunia pod dwiema postaciami..., dz. cyt., s. 42; J. Bochenek, Stanislawa Hozjusza nauka o Eucharystii..., dz. cyt., s. 133; A. Szorc, Hozjusz a reformacja w Elblqgu, Studia Warmińskie 7 (1970) s. 64.

"S. Kot, Andrzej Frycz Modrzewski..., dz. cyt., s. 90.

${ }^{83}$ Sobór Trydencki (1545-1563) trwał osiemnaście lat z dwukrotnymi dłuższymi przerwami. Dzieli się on więc wskutek tego na trzy następujące okresy: 1. od 13 grudnia 1545 r. do 14 września 1549 r. (sesje od pierwszej do dziesiątej) za papieża Pawła III, przy czym w marcu 1545 r. został przeniesiony do Bolonii; 2 od 1 maja 1551 r. do 28 kwietnia 1552 r. (sesje od jedenastej do szesnastej) za papieża Juliusza III; 3. od 18 stycznia 1562 r. do 4 grudnia 1563 r. (sesje od siedemnastej do dwudziestej piątej) za papieża Piusa IV. Zob. J. Gręźlikowski, Recepcja reformy trydenckiej w diecezji wlocławskiejw świetle ustawodawstwa synodalnego, Włoclawek 2000, s. 49.

${ }^{\star 4}$ H. D. Wojtyska, Polacy na soborze Trydenckim..., art. cyt., s. 100.

${ }^{85} \mathrm{~J}$. Mielczarek, Komunia pod dwiema postaciami..., dz. cyt., s. 124.

${ }^{86}$ Tamże, s. 137.
} 
nodu narodowego przez prymasa Jakuba Uchańskiego. Kilkakrotne próby zwolania potrydenckiego synodu prowincjonalnego dla prowincji gnieźnieńskiej zostały udaremnione przez ówczesnego nuncjusza Commendoniego, na polecenie Stolicy Apostolskiej. Powodem takiej reakcji i działania ze strony nuncjusza byla niejednoznaczna postawa samego prymasa, podatnego na wplywy protestantyzmu i wiążąca się z tym możliwość zwolania synody narodowego ${ }^{87}$.

Idea samego synodu narodowego została wysunięta w roku 1556 - w trakcie trwania Tridentinum i po jego zakończeniu przez innowierców, domagających się od króla uregulowania nabrzmiałych problemów religijnych, w tym Komunii pod dwiema postaciami oraz równouprawnienia z Kościołem katolickim. Ząania tego typu ponawiane przez posłów innowierczych na kilku kolejnych sejmach zyskały przychylność króla Zygmunta Augusta, który dostrzegał w synodzie narodowym szansę przeprowadzenia unieważnienia własnego małżeństwa. Prymas Uchański także skłaniał się ku idei takiego synodu, widząc w nim możliwość rozwiązania szeregu kwestii religijnych i kościelnych ${ }^{88}$. Nic więc dziwnego, że reakcja Stolicy Apostolskiej była w tym względzie jednoznaczna. Jakkolwiek prymasowi udalo się nawet wyznaczyć konkretne daty zwołania synodu do Piotrkowa, między innymi na 17 grudnia 1564 r., a więc wkrótce po przyjęciu uchwał trydenckich przez króla, co miało miejsce w tym samym roku ${ }^{89}$, a następnie na 14 października $1565 \mathrm{r}$. $-z$ jednoczesnym podaniem treści obrad do publicznej wiadomości, jednakże próby te zostały udaremnione i zahamowane przez negatywną reakcję ze strony króla, co było przejawem między innymi dyplomatycznych zabiegów nuncjusza ${ }^{90}$.

Stworzyła się więc nieco skomplikowana sytuacja. Stolica Apostolska czyniła zabiegi, aby jak najszybciej dokonano recepcji uchwał try-

${ }^{87}$ W. Góralski, Reformistyczne synody plockie na przelomie XVI i XVII wieku, Plock 1983, s. 14; W. Wójcik, Kościelne ustawodawstwo partykularne w Polsce przedrozbiorowej na tle powszechnego prawodawstwa kościelnego, w: Księga Tysiąclecia Katolicyzmu w Polsce, t. I, Lublin 1969, s. 437-438.

${ }^{88}$ A. Pawiński, Synod piotrkowski w roku 1577, w: Źródta dziejowe, t. IV, Warszawa 1877, s. III; Zob. S. Nasiorowski, List pasterski..., dz. cyt., s. 22.

${ }^{89}$ P. Aleksandrowicz, Przyjęcie przez króla i senat uchwat Soboru Trydenckiego w Parczewie w 1564 roku, Prawo Kanoniczne 9 (1966) nr 3-4, s. 217-219.

${ }^{{ }_{0}}$ I. Subera, Synody prowincjonalne arcybiskupów gnieźnieńskich, Warszawa 1981, s. 107; Zob. A. Pawiński, Synod piotrkowski w roku 1577 ..., art. cyt., s. V-VI. 
denckich w poszczególnych krajach, a więc także i w Polsce, a z drugiej strony czuwała nad prawidłowością ich przyjęcia. Król Zygmunt August przyjmując dekrety soborowe spodziewał się szybkiego uporządkowania w państwie problemów religijnych. Wydaje się, iz potrzeba wprowadzenia reformy szczególnie mocno nurtowała także hierarchię kościelną, która w prawodawstwie soborowym dostrzegała możliwość wzmocnienia podupadłej dyscypliny w szeregach du-

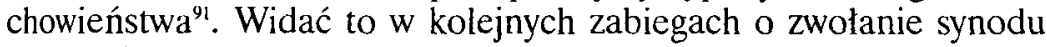
prowincjalnego, tym razem zainicjowanych w 1567 r. przez kardynała Stanisława Hozjusza, a potem przez biskupa włocławskiego Stanisława Karnkowskiego. Z listów obydwu hierarchów wynika, że dostrzegali oni konieczność zwołania synodu - oprócz wskazanych wyżej motywów - w celu podjęcia zdecydowanych działań przeciwko szerzącym się atakom na Kościól ze strony innowierców ${ }^{92}$. Jednak i te próby zwołania synodu zakończyły się niepowodzeniem, gdyż z jednej strony udaremnia je zwołanie przez króla kolejnego sejmu, a z drugiej niechętne tym razem stanowisko prymasa Uchańskiego ${ }^{93}$. Jakkolwiek w okresie bezkrólewia powstałego po śmierci Zygmunta Augusta wzrosła pozycja prymasa Uchańskiego, który tymczasowo objąt władzę polityczną w kraju, niemniej jednak i tym razem nie udało się mu przeforsować myśli zwolania synodu obok zwolanego na początek 1573 r. sejmu konwokacyjnego, którego celem miało być ustalenie porządku elekcji nowego władcy. Dostrzegając i tym razem możliwość przerodzenia się synodu prowincjalnego w synod narodowy, nie dopuszczali do niego wpływowi biskupi Hozjusz i Karnkowski. Można dziś powiedzieć, iż były to zabiegi mimo wszystko słuszne, zwłaszcza gdy zważy się efekt konfederacji warszawskiej z 1573 r., która wprowadziła zupełne równouprawnienie wszystkich wyznań, co było dotkliwym ciosem dla Kościoła katolickiego zadanym przez innowierców. W takim kontekście planowany synod, co do zwołania którego nalegały także kapituly naciskając na posłów, aby prowadzili pertraktacje ze Stolicą Apostolską w sprawie zawieszenia egzekucji uchwał soborowych zakazujących

\footnotetext{
"T. Silnicki, Sobory powszechne a Polska, Wroclaw 1962, s. 123-124.

${ }^{92}$ A. Chmielewski, Zyciorys Księdza Stanistawa Kankowskiego, Arcybiskupa Gnieźnieńskiego, Warszawa 1884, s. 147-150.

${ }_{93}$ A. Pawiński, Synod piotrkowski..., art. cyt., s. VII; Zob. S. Nasiorowski, List pasterski..., dz. cyt., s. 22-23.
} 
kumulowania beneficjów i zobowiązujących do rezydencjiis ${ }^{94}$, mógłby mieć również nieobliczalne skutki ${ }^{45}$.

Od chwili przyjęcia dekretów soborowych przez króla i potem przez prowincję lwowską upłynęło trzynaście lat oczekiwań zanim doszlo do zmiany sytuacji i do przyjęcia tychże dekretów w metropolii gnieźnieńskiej. Dlatego uchwały soborowe stały się wcześniej przedmiotem obrad szeregu synodów diecezjalnych, zwoływanych przez poszczególnych biskupów w obydwu prowincjach kościelnych ${ }^{*}$, m.in. synodu włocławskiego biskupa Stanisława Karnkowskiego z 1568 r. ${ }^{97}$

Po latach oczekiwań bardziej korzystna sytuacja odnośnie do przyjęcia uchwał Tridentinum zaistniała dopiero po wstąpieniu na tron Stefana Batorego, który zamierzał między innymi uporządkować sprawy religijne kraju ${ }^{98}$. Chociaż prymas Uchański urażony o przywilej koronacji nowego króla, przyznanej przez sejm biskupowi Stanisławowi Karnkowskiemu, początkowo - z racji ambicjonalnych - zająl negatywne stanowisko wobec synodu, to jednak w rezultacie pertraktacji i zabiegów Karnkowskiego oraz innych wplywowych osób wyraził swoją aprobatę w tej sprawie ${ }^{99}$.

W lutym 1577 r. zostały rozesłane drukowane propozycje, zawierające treść przyszłych obrad. 1 kwietnia został ogłoszony przez prymasa Uchańskiego specjalny okólnik w sprawie synodu. Ideę przewodnią tych dokumentów nurtowała z pewnością myśl, którą widać $\mathrm{w}$ uprzednio toczących się pertraktacjach między prymasem a biskupem Karnkowskim o zwołanie synodu. Biskup Karnkowski uzasadniał potrzebę przyjęcia podczas obrad synodalnych dekretów trydenckich, które arcybiskup gnieźnieński z kolei negował, jako nie dające się zastosować w prowincji gnieźnieńskiej. W rezulta-

${ }^{4}$ W. Wójcik, Kościelne ustawodawstwo partykularne..., art. cyt., s. 438.

${ }^{95}$ A. Pawiński, Synod piotrkowski..., art. cyt., s. 11.

\% Zob. P. Katwa, Rys historyczny prowincjonalnego ustawodawstwa synodalnego w Polsce przedrozbiorowej, w: Ksiega pamiatkowa ku czci J. E. Ks. Biskupa Mariana Leona Fulmana, cz. 1, Lublin 1939, s. 149.

${ }^{97}$ Zob. Acta synodi dioecesanae Wladislaviae, anno 1568 per Stanislaum Karnkowski Episcopum celebratae [...], w: Z. Chodyński, Statuta synodalia dioecesis Wadislaviensis et Pomeraniae, Varsaviae 1890, s. 38-79.

${ }^{9}$ W. Góralski, Reformistyczne synody plockie..., dz. cyt., s. 14; Zob. S. Gruszecki, Walka o wladze w Rzeczypospolitej po wygaśnięciu dynastii Jagiellonów (1572-1573), Warszawa 1969, s. 28-33.

${ }^{99}$ A. Pawiński, Synod piotrkowski..., art. cyt., s. XV. 
cie nalegań i zabiegów, Karnkowski z całą pewnością inspirator zwołania synodu w końcowej fazie jego przygotowań - przedłożyl prymasowi bezwzględną konieczność przyjęcia dekretów soborowych, uzasadniał również, że o ile zajdzie potrzeba złagodzenia pewnych rygorów prawa dla prowincji gnieźnieńskiej, należy bezzwłocznie zwrócić się do Stolicy Apostolskiej z odpowiednio przygotowanymi petycjami ${ }^{(x)}$.

Poza tym myśl zwołania nowego synodu musiała samorzutnie inspirować okres szesnastu lat, jaki upłynął od poprzedniego synodu prowincjalnego w $1551 \mathrm{r}$. Jak świadczą o tym opracowania dotyczące tego okresu, nagromadzilo się mnóstwo materiałów na obrady synodalne. Ich źródłem były z pewnością same dekrety trydenckie, niekiedy stanowiące już wcześniej impuls dla reformatorkich dzialań synodów diecezjalnych, następnie wyniki wizytacji przeprowadzonych w diecezjach, świadczące o rozluźnieniu dyscypliny w szeregach duchowieństwa, sprawy religijne, polityczne czy wreszcie często nabrzmiałe problemy godzące w prawa Kościoła i wykonywana przezeń jurysdykcję $e^{101}$.

W rezultacie wszelkich zabiegów ustalono datę zwołania synodu do Piotrkowa na 19 maja 1577 r. ${ }^{102}$ Synod odbył się pod przewodnictwem prymasa Jakuba Uchańskiego w obecności przybyłego również nuncjusza Wincentego Laureo. Całość problematyki synodalnej została gruntowanie przeanalizowana przez uczestników podczas kolejno następujących po sobie pięciu sesji synodalnych. Każdy dzień obrad poświęcony był odrębnej sesji. Synod reprezentując cały Kościół w Polsce, po wielu latach oczekiwań, przyjął uroczyście (sine ulla exceptione, sancte et reverenter) już $\mathrm{w}$ pierwszej uchwale synodalnej dekrety dogmatyczne i reformistyczne Tridentinum w imieniu całej prowincji gnieźnieńskiej, zobowiązując się wypełniać w całości zawarte w nich dyspozycje ${ }^{103}$. Podczas tej samej

"100 Tamże, s. 13.

${ }^{101}$ S. Nasiorowski, List pasterski..., dz. cyt., s. 24; Zob. T. Glemma, Wizytacje diecezji krakowskiej z lat 1510-1570, Nasza Przeszlość 1 (1946) 43; Zob. Także S. Librowski, Wizytacje diecezji wloclawskiej, cz. 1 - wizytacje diecezji kujawskiej i pomorskiej, t. I - opracowanie archiwalno-źródtoznawcze, cz. 1 - wizytacje w latach 1123-1421, Lublin 1965, s. $80-83$ oraz $126-132$.

${ }^{102}$ I. Subera, Synody prowincjonalne..., dz. cyt., s. 107.

${ }^{103}$ Constitutiones synodorum metropolitanae ecclesiae Gnesnensis provincialium authoritatae synodi provincialis Gembicianae per deputatos recognitae, iussu vero et opera [...] Joannis Wężyk [...] editae, Cracoviae 1630, s. 349. 
sesji wybrano również komisję do spisywania konstytucji synodalnych. Jej przewodniczącym został biskup Stanisław Karnkowski, a w skład weszlo kilku opatów i reprezentantów kapitu1 ${ }^{104}$. Jednocześnie synod postanowił zwrócić się do papieża o zawieszenie przepisów o kumulacji beneficjów i rezydencji, nadto złożył uroczysty protest przeciwko konfederacji warszawskiej ${ }^{105}$.

Oficjalne przyjęcie uchwał Soboru Trydenckiego na synodzie piotrkowskim w 1577 roku rozpoczęło długi proces wdrażania do rodzinnego ustawodawstwa kościelnego reformistycznych postanowień soborowych. Recepcja dekretów soborowych, także w odniesieniu do uregulowań Komunii pod dwiema postaciami, wymagała dostosowania prawa patrykularnego go nowych ustaw powszechnych. Należało go zatem skodyfikować, aby w ten sposób zreformować ważniejsze dziedziny życia religijnego, w tym także uregulować kwestie związane ze sporną sprawą udzielania i przyjmowania Komunii utrakwistycznej.

Jak wspomniano żądanie Komunii pod dwiema postaciami było postulatem katolickich reformatorów. Nawet na Soborze Trydenckim przedstawiciele Polski nie przemawiali jednym głosem, co odzwierciedlało złożoność problemu. Polskie synody potrydenckie podejmując sprawę Komunii pod dwiema postaciami występowały w obronie Komunii pod postacią chleba. Ważne w tym względzie są postanowienia synodów włocławskich biskupa Stanisława Karnkowskiego z $1568^{106}$ i 1579 roku $^{107}$. Mając na uwadze silne wpływy protestantyzmu na terenie diecezji kujawskiej i pomorskiej oraz pragnąc usunąć wszelkie wątpliwości, powolując się na postanowienia Soboru Trydenckiego, biskup Karnkowski wyjaśnial i nakazywał duszpasterzom nauczać o tym wiernych, iz przyjmujac Komunię święta pod postacia chleba przyjmuja prawdziwy sakrament $i$ catego Chrystusa i nie przyjmuja mniejszego duchowego owocu, niż

${ }^{104}$ A. Pawiński, Synod piotrkowski..., art. cyt., s. XIX; T. Glemma i M. Banaszak, Przyjeccie reformy trydenckiej w Kościele Polskim. W: Historia Kościola w Polsce..., dz. cyt., t. I, cz. 2, s. 175 .

${ }^{105}$ W. Wójcik, Kościelne ustawodawstwo partykularne..., art. cyt., s. 438; T. Glemma i M. Banaszak, Przyjęcie reformy trydenckiej..., art. cyt., s. 175.

${ }^{106}$ Acta Synodi Dioecesanae Wladislaviae Anno 1568 per Stanislaum Karnkowski Episcopum celebratae, pars. I, tit. II. Z. Chodyński, Statuta synodalia..., dz. cyt., s. 62.

${ }^{1107}$ Secunda Synodus Dioecesana Stanislai Karnkowski, Wladislaviae Anno Domini 1579 celebrata. Tamże, s. 83 . 
gdyby przyjmowali Go pod dwiema postaciami ${ }^{108}$. Nakaz ten został w statutach bardzo mocno zaakcentowany stwierdzeniem biskupa, że nauka Nauczycielskiego Urzędu Kościola jest pewna i duchowni $i$ wierni winni ja wypetniać, ci zaś którzy nie przyjmuja Eucharystii nie moga sie nazywać chrześcijanami ${ }^{10 y}$. Ponownie bardzo mocno sprawę Komunii świętej pod postacią chleba stawial drugi synod biskupa Karnkowskiego z 1579 r., powolując się na synod prowincjalny piotrkowski z 1577 r., przytaczający dekret Cum in nonnulius Soboru w Konstancji ${ }^{110}$, prawodawca raz jeszcze przypominal obowiązek udzielania i przyjmowania Komunii świętej pod postacią chleba. ${ }^{111}$

Wyraźnie zabraniały Komunii sub utraque specie synody: wrocławski z 1580 roku $^{112}$, wileński z 1582 roku ${ }^{13}$ oraz chełmiński z 1583 roku $^{14}$. Sprawą przyjmowania Komunii świętej pod jedną postacią chleba zajął się również włocławski synod diecezjalny biskupa Rozrażewskiego z roku 1586. W artykule Circa sacramentum Eucharistiae, potępiając postulaty wysuwane przez protestantyzm na terenach diecezji, synod postanawiał, że Najświętsze Ciało i Krew Chrystusa mogą być udzielane tylko pod postacią chleba, wszystkim tym, którzy wcześniej przez sakramentalną spowiedź - połączoną z dostatecznym żalem - oczyścili się z grzechów ${ }^{115}$.

Należy przytoczyć również postanowienia synodu prowincjalnego piotrkowskiego z 1577 roku, przytaczającego dekret Cum in nonnullis

Acta Synodi Dioecesanae Wladislaviae anno 1568 per Stanislaum Karnkowski episcopum celebratae. Tamże, s. 62.

${ }^{109}$ Acta synodi Dioecesanae Wladislaviae anno 1568 per Stanislaum Karnkowski episcopum c. Tamże, s. 62.

${ }^{110}$ Constitutiones synodorum metropolitanae Gnesnensis provincialium tam vestutorum quam recentiorum usque ad annum MDLXXVIII. Studio et opera [...] Stanislai Karnkowski [...] Cracoviae 1579, s. 96-97, Decretum Sacri Concilii Constantiensis de Communione sub utraque specie.

"II Secunda Synodus Dioecesana Stanislai Karnkowski, Wladislaviae Anno Domini 1579 celebrata, Z. Chodyński, Statuta synodalia..., dz. cyt., s. 83.

${ }^{12}$ Acta et Constitutiones Synodi Dioecesanae Dominus Martinus Episcopus Wratislaviensis a. 1580 celebravit. M. Montbach, Statuta synodalia Sanctae Ecclesiae Wratislaviensis, Wratislaviae 1855, s. 233.

${ }^{113}$ Synodis Wilnensis a. 1582. J. Sawicki, Concilia Poloniae. Źródta i studia krytyczne, t. II, Synody diecezji wileńskiej $i$ ich statuty, Warszawa 1948, s. 136-137.

${ }^{11}$ Synodus Culmensis a. 1583. A. Mańkowski, Constitutiones synodales necnon ordinationes dioecesis Culmensis, Torunii 1929, s. 43.

${ }^{115}$ Acta et Constitutiones Synodi Dioecesanae Wladislaviensis (primae) habite et celebratae, A. D. 1586. Tamze, s. 112. 
soboru w Konstancji ${ }^{116}$, a także Katechizm Trydencki przetłumaczony przez Stanisława Karnkowskiego jako prymasa ${ }^{117}$, które powtarzały i przypominały naukę Tridentinum na temat Komunii pod dwiema postaciami, zobowiązując wiernych do przyjmowania Komunii pod postacią chleba.

Zdecydowanie i obszernie nawoływał do powrotu do Komunii pod postacią chleba synod wrocławski z 1592 roku $^{118}$. Albowiem udzielony indult z 1564 roku zezwalający na komunikowanie pod obiema postaciami rozpowszechnil się bardzo szybko i tym bardziej potrzeba było stanowczych decyzji i rozporządzeń wprowadzających Komunię pod postacią chleba. Prawodawca synodalny nakazał więc duchowieństwu uczyć w szkole dzieci i młodzież, że przyjmując Komunię świętą pod postacią chleba przyjmują prawdziwy sakrament i zachęcać do zaprzestania utrakwistycznej praktyki przez wiernych. Uchwała synodalna miała na celu przyzwyczajanie wiernych do przyjmowania Ciała Chrystusa pod jedną postacią i wybiegała naprzód, albowiem - jak wspomniano - indult papieski upoważniający do udzielania Komunii pod dwiema postaciami odwołano dla Wrocławia w 1597 roku, a już wcześniej, bo w roku 1584 papież Grzegorz XIII odwołała udzielone indulty dla Niemiec, Austrii, Węgier i Czech, a diecezja wrocławska należała wtedy do czech, a czym wspomina w statutach prawodawca.

$\mathrm{Na}$ tle reformistycznych tendencji ukazuje się w sposób szczególny postać Stanisława Hozjusza, który niestrudzenie pracował nad umocnieniem katolicyzmu w Polsce. Osią wokół której obracały się jego starania, rozmowy i zabiegi była właśnie sprawa Komunii pod dwiema postaciami. Hozjusz między innymi zabiegał o zwołanie sy-

${ }^{116}$ Constitutiones synodorum metropolitanae Gnesnensis provincialium tam vestutorum quam recentiorum usque ad annum MDLXXVII. Studio et opera [...] Stanislai Karnkowski [...] Cracoviae 1579, s. 96-97. Decretum Sacri Concilii Constantiensis de Communione sub utraque specie.

${ }^{117}$ Katechizm Rzymski z dekretu S. Koncylium Tydenckiego za rozkazem S. Piusa $\checkmark$ papieza po lacinie wydany na jezyk polski powaga [... J Stanistawa Kamkowskiego, arcybiskupa Gnieźnieńskiego, Prymasa, przez pytania i odpowiedzi przetlumaczony [...] ks. Felicjanowi Wolodkowiczowi arcybiskupowi metropolicie kijowskiemu [...] oraz arcybiskupom i biskupom i duchowieństwu [...] wydrukowany w Wilnie I762 roku, s. 137-138.

${ }^{118}$ Acta et Constitutiones Synodi Wratislaviae Anno MDXCII. M. Montbach, Statuta synodalia Sanctae Ecclesie Wratislaviensis, Wratislaviae 1855, s. 208; Por. J. Sawicki, Concilia Poloniae. Źródla i studia krytyczne, t. X, Synody diecezji wroclawskiej i ich statuty, Wrocław-Warszawa-Kraków 1963, s. 630-631; W. Urban, Eucharystia w świetle ustaw synodów..., art. cyt., s. 234. 
nodu prowincjalnego już w 1551 roku, aby znaleźć skuteczne środki do ochrony zagrożonego przez reformację katolicyzmu ${ }^{114}$. Synod opracował wyznanie wiary, którego duszą był Hozjusz. Wyznanie to wydane na synodzie piotrkowskim w 1554 roku było dla duchowieństwa i wiernych przewodnikiem wśród nowości religijnych, w tym Komunii utrakwistycznej, jak również pomocą w odparciu zarzutów ${ }^{120}$.

Z czasem jednak umysły w Polsce uspokoiły się, uchwały soboru Trydenckiego zrobiły swoje i ostudziły żądania i zamiary; zapędy reformatorskie wśród katolików ucichły, co miało wpływ na dalszy rozwój katolicyzmu w Polsce. Po soborze Trydenckim przez cztery następne stulecia zwyczajną i powszechną praktyką była Komunia pod jedną postacią. Jednakże w tym okresie istniały nadal, także w Polsce, nieliczne wprawdzie, przypadki korzystania z Komunii pod obiema postaciami. W literaturze teologiczno-kanonicznej zasadniczo idą autorzy po linii nauki trydenckiej, choć pojawiały się sporadyczne głosy na rzecz kielicha dla świeckich. Dopiero w XIX wieku przychodzą ustawodawcze decyzje papieży w tej sprawie w związku z problemem współdziałania obrządków katolickich o odmiennej praktyce Komunii. Te rozstrzygnięcia przyjął Kodeks Prawa Kanonicznego z 1917 roku, który jednocześnie potwierdził, jako obowiązujące prawo w Kościele katolickim, dotychczasowy sposób udzielania i przyjmowania Komunii świętej tylko pod postacią chleba ${ }^{121}$.

\section{Zakończenie}

Na przelomie XII i XIII wieku w Kościele Zachodnim przyjął się na drodze zwyczaju ryt Komunii tylko pod postacią chleba. Było to $\mathrm{z}$ jednej strony uzasadnione racjami teologiczno-praktycznymi, lecz $z$ drugiej strony stanowiło zerwanie $z$ pierwotna tradycja Kościoła, a przede wszystkim z przykładem samego Chrystusa z Ostatniej Wieczerzy. Ten drugi moment stał się od początku XV wieku istotnym elementem rozważań i polemik dotyczących Eucharystii w tym i Komunii. Problem Komunii pod dwiema postaciami podniesiono w Polsce w dość złożonym nurcie teologicznym i społeczno-politycznym, co zresztą odnosiło się do całej ówczesnej Europy. Mia-

\footnotetext{
${ }^{119}$ J. Bochenek, Stanistawa Hozjusza nauka o Eucharystii..., dz. cyt., s. 21-22.

${ }^{120}$ Tamże, s. 22-23.

${ }^{221}$ J. Mielczarek, Komunia pod dwiema postaciami..., dz. cyt., s. 137.
} 
nowicie już pod koniec XIV wieku w praskim środowisku zrodziła się nowa myśl teologiczno-reformatorska, która pod wpływem Jana Wiklifa, jak również w kontekście ówczesnej sytuacji kościelnej, społecznej i politycznej przekształciła się w ruch religijno-spoleczny pod ideowym przewodnictwem Jana Husa i Hieronima $z$ Pragi, zwany husytyzmem. W nurcie husyckiej ideologii znalazła się idea Komunii pod dwiema postaciami, która trafiła bardzo szybko do Polski. Podnoszona kwestia i żądania udzielania wiernym Komunii kielicha kolidowała z powszechnym zwyczajem komunikowania pod postacią tylko chleba. Wobec takich poglądów i praktycznych działań zmierzających do ponownego wprowadzenia Komunii pod dwiema postaciami, Kościól musial zajmować i określać swoje stanowisko $\mathrm{i}$ dyscyplinę $w$ tej kwestii. Wyrażało się ono zasadniczo uchwałami soborów, postanowieniami papieży i Stolicy Apostolskiej. Zostało w ten sposób wypracowane ustawodawstwo kościelne normujące doktrynę i dyscyplinę Komunii tamtego czasu, szczególnie zaś Komunii sub utraque specie. Ustawodawstwo to należało wprowadzić w życie Kościoła w Polsce poprzez uchwały synodów prowincjalnych i diecezjalnych.

Należy powiedzieć, że polskie statuty synodalne okresu przedrozbiorowego starały się wywiązać w sposób należyty, aczkolwiek w dużym stopniu zależało to od samych biskupów diecezjalnych, gdyż to oni byli ustawodawcami synodalnymi. Trzeba było pokonać wiele trudności, wykazać stanowczość i troskę o dyscyplinę życia eucharystycznego i sposób udzielania Komunii, aby przepisy prawa powszechnego wprowadzić w życie. Stąd uchwały synodalne tego okresu stanowią jedno ze znakomitszych źródel poznania warunków w jakich Kościół w Polsce żył i działał. Dostarczają obfitego i bogatego materiału określającego i normującego każdą sferę życia religijnego i kościelnego, w tym także - jak mogliśmy zobaczyć i co było celem opracowania - kwestię Komunii pod dwiema postaciami. Prawodawcy synodalni zabiegając o dobro duchowe wiernych oraz dyscyplinę sprawowania i sposobu udzielania sakramentu Eucharystii określali, w oparciu o prawo powszechne, normy prawne jakie należało przestrzegać i zachowywać w życiu Kościola w Polsce. Kształtowały one tym samym życie i postawę duchowieństwa i wiernych w zakresie sposobu udzielania Komunii świętej.

Kontrowersyjna kwestia Komunii pod dwiema postaciami nie byla przedmiotem zainteresowania wielu synodów prowincjalnych 
czy diecezjalnych. Wynikalo to z faktu, iż nie we wszystkich diecezjach ówczesnej Polski idea Komunii kielicha była tak silna, a tym samym wymagająca wypowiedzi i uregulowań prawnych. Uchwały takie podejmowali ci biskupi, których diecezje były narażone w większym stopniu początkowo na wpływy husyckie, a później na protestanckie (chełmska, wrocławska, włocławska, chełmińska). Uchwały tych były uzasadnione merytorycznie, stanowcze, jednoznaczne i wzywające do przestrzegania określonego sposobu udzielania Komunii pod postacią chleba. Bardzo ważnym elementem, a zarazem pierwszym ważnym śladem polskiego ustawodawstwa synodalnego $w$ omawianej kwestii były uchwały synodu diecezji chełmskiej z 1440-1441 roku, w którym to biskup Jan Biskupiec umieścił szeroko rozbudowany traktat apologetyczny zatytułowany Sequitur de communione Venerabilis Sacramenti, a dotyczący Komunii pod dwiema postaciami, na który powoływały się niektóre synody późniejsze. Ważną i znaczącą rolę we wprowadzaniu w życie Kościoła polskiego Komunii pod postacią chleba miały uchwały synodów potrydenckich. Nie wszystkie jednak tę kwestię podejmowały, mimo iz zawierały uchwały na temat Eucharystii. Widocznie ustawodawcy synodaini byli zdania, iż nie było takiej potrzeby.

\section{Communion under two forms in synodal legislation of preparation Poland}

In the midst of numerous of controversy concerning the Eucharist in the history of Church, the way of taking the Holy Communion by the faithful comes to the lading place. It refers especially to the question of taking the Communion under two forms. For almost thirteen centuries, in Western Church, the usual and common practice of administering the Holy Communion to the faithful was the Communion in form of bread and wine. On the turn of XII-th and XIII-th century, by means of custom, practice of Communion under one form - bread - became accepted and it has constituted the common rule for almost seven centuries, until The II-nd Vatican Council, which decided to restore Communion under two forms within the limited range, and this was legitimized by Canonical Law Code from year 1983.

Introduction of Communion on the form of bread was justified from one side by theological - practical reasons, but from the other side it constituted breach with primeval tradition of the Church, and first of all with example of Jesus Christ Himself from the Last Supper. This second moment became, on the beginning of $\mathrm{XV}$-th century, a substantial element of considerations and polemics concerning the Communion, starting the movement for reclaim of Communion 
in two forms for the secular faithful. This movement appeared and developed itself in wide trend of Hussitism, and later it reappear with much stronger force in time of protestant reformation. Facing demands to introduce the Communion in two forms, the Church had to define its point of view and discipline in this question. It was basically expressed in resolutions of councils, decisions of popes and the Apostolic See.

The movement demanding introduction of Communion under two forms had also wide repercussion in Polish synodal legislation, which had the goal to enforce common law that refer to a way of taking the Holy Communion. Synodal legislators, based on the law, determined common law principles, which should be observed and followed within the range of administering the Holy Communion. Controversial question of Communion under two forms was not a subject of interest of too many provincial or diocesan synods. It resulted from the fact, that not in every dioceses of Poland in those times, idea of Communion under two forms was as strong, thus requiring to be regulated by the law. Such resolutions were passed by these bishops, whose dioceses were exposed in bigger degree on Hussite influences first, and protestant influences later (it applies to the following dioceses: chelmska, wrocławska, włocławska and chelmińska). Resolutions of synods of these dioceses were essentially justified, definitive, unequivocal and calling to observe specific way of administering the Communion under form of bread. 